\title{
References:
}

1. Beasley J. C. Tobias Smollett: Novelist. Athens, London: The University of Georgia Press, 1998. 259 p.

2. Boege F. W. Smollett's Reputation as a Novelist. Princeton, New York: Princeton University Press, 1947. 175 p.

3. Bouce P.-G. The Novels of Tobias Smollett. London, New York: Longman, 1976. $406 \mathrm{p}$.

4. Evans J. E. 'An honest scar received in the service of my country': Lismahago's Colonial Perspective in 'Humphry Clinker'. Philological Quarterly. Vol. 79. Fall 2000, No. 4. P. 483-499.

5. Giddings R. The Tradition of Smollett. London: Methuen and Co, Ltd, 1967. $215 \mathrm{p}$.

6. Giddings R. Tobias George Smollett. London: Greenwich Exchange, 1995. $76 \mathrm{p}$.

7. Knapp L. M. Tobias Smollett. Doctor of Men and Manners. Princeton, New Jersey: Princeton University Press, 1949. 362 p.

8. Mayer R. History, 'Humphry Clinker' and the Novel. EighteenthCentury Fiction. Vol. 4. No. 3, April, 1992. P. 239-255.

9. Skinner J. Constructions of Smollett: a study of genre and gender. Newark, London: University of Delaware Press, 1996. 267 p.

10. Spector R. D. Tobias George Smollett. New York: Long Island University. Twayne Publishers, Inc., 1968. 175 p.

11. Tobias Smollett. The Critical Heritage / ed. by Lionel Kelly. London, New York: Routledge and Kegan Paul, 1987. 380 p.

DOI https://doi.org/10.30525/978-9934-26-073-5-1-41

\section{ВІЗІЇ ЧЕРВОНОЇ ПЛАНЕТИ В АМЕРИКАНСЬКІЙ НАУКОВО-ФАНТАСТИЧНІЙ ЛІТЕРАТУРІ ХХ СТОЛІТТЯ}

\author{
Сластьонова Д. С. \\ здобувачка другого (магістерського) рівня вищої освіти \\ Бердянського державного педагогічного університету \\ м. Бердянськ, Запорізька область, Украӥна
}

Американська література першої половини XX століття зазнала істотних змін у жанрово-стильовому вимірі. Раніше популярні пригоди, вестерни та любовні романи вже не приваблювали публіку та авторів. Бурхливі історичні події, урбанізація, інтенсивний розвиток індустрії й 
комунікацій, науково-технічна революція дали поштовх до опанування нових тем. Космічна тема, зокрема тема Марсу, стала актуальною на той час, що зумовлено активним розвитком науки, технологій і орієнтацією США на колонізацію інших планет. Ця проблематика дала змогу поновому висвітлити одвічні філософські питання про сутність людини i перспективи людства, розкриваючи їх у космічному масштабі.

Актуальність дослідження пояснюється тим що образність науковофантастичних романів першої половини XX століття, зокрема образ Марсу і його жителів, не була достатньо висвітлена літературознавцями, хоча становить велику цінність для розуміння природи фантастичного та розвитку американської і світової фантастики в цілому.

Метою дослідження $є$ аналіз образів Марсу та марсіанина в американській науково-фантастичній літературі XX століття на основі творів Е. Р. Берроуза «Принцеса Марсу», Р. Хайнлайна «Червона планета», Р. Бредбері «Марсіанські хроніки». Теоретичною основою нашого дослідження стали праці, Кена Гелдера «Popular Fiction: The Logic and Practices of a Literatury Field» Роберта Крослі «Imagining Mars: A Literary History», студії про фантастику, зокрема стаття Лідії Зелінської «Комунікація з Чужим (огляд європейської і американської літературної марсіади з кінця XIX ст. до початку XXI ст.)» та інші.

Планета Марс приваблювала фантастів віддаленістю, загадковістю та незвичністю. Наукові студії і гіпотези віддзеркалювалися в літературних творах. Опис цієї планети істотний для подальшого аналізу згаданих творів, адже кожен з авторів зображує Марс по-різному: Е. Р. Берроуз бачить Барсум (Марс) як вимираючу планету, яка потерпає від природніх катастроф і воєн, Р. Бредбері та Р. Хайнлайн осмислюють колонізацію цієї планети як перехідний етап для порятунку життя на Землі та втечу від політичного режиму.

У романі Едгара Райза Берроуза «Принцеса Марсу» (1912) (Edgar Rice Burroughs «A Princess of Mars») Барсум описаний як величезна пустеля 3 руїнами старовинних міст, океани якого майже спустошені, а атмосфера розріджена. Берроуз заселяє Марс різними расами. Одні 3 них - червоні марсіани, які виглядають як люди, але мають червону шкіру. Їхні головні міста - Геліум та Зоданга - перебувають у стані довготривалої війни, саме тому їхня наука стоїть на місці, використовують марсіани досягнення предків. Також планету населяють і кочові варвари Тарки - зелені марсіани, утричі більші за звичайну людину та мають по чотири руки. Тарки мешкають у зруйнованих містах минулого, деякі помешкання в них чимось нагадують земні будинки, наприклад, наявністю картин та скульптур, що ніби повертають нас до сучасного не фантастичного, а всі їхні технології були вкрадені у червоних марсіан. 158 
Важливим моментом $є$ зображення героїні роману - марсіанської принцеси Деї Торріс. Антропоморфність героїні дає змогу проаналізувати схожі якості землян та марсіан. В портретуванні героїні можна помітити схильність Берроуза до зображення Деї Торріс саме як «ідеальної марсіанки» - тієї бажаної пари для головного героя, землянина Джона Картера, та бажаної для масової культури того часу образу жінки [1].

У «Марсіанських хроніках» Р. Бредбері (1950) (Ray Bradbury «The Martian Chronicles») знаходимо на Марсі канали, заповнені водою, та високорозвинену марсіанську цивілізацію. Марсіани Бредбері - мудра та надзвичайно красива раса. Вони мають коричневу шкіру, золоті очі, глибокий ніжний голос та охайні фігури. Марсіани живуть у прекрасних містах та мають приголомшливі технології. Наприклад, вирощують золоті фрукти на кришталевих колонах, використовують літальні автівки, книги, що розмовляють, навіть телепатію [3]. Земляни в порівнянні 3 марсіанами виглядають неосвіченими варварами. Марсіани у творі гинуть від земних мікробів. Як ми бачимо, в цьому творі також присутня тема першого контакту, але представлена вона в абсолютно протилежному ключі, ніж, наприклад, у романі «Війна світів» Г. Веллса. У «Марсіанських хроніках» прибульцями є самі люди, тобто тут ми маємо справу з інверсією мотиву. Людські мотиви тут визначити складно до останнього розділу: незрозуміло, чого ж вони дійсно хочуть: поневолити і згодом знищити марсіанську расу або жити в мирі та злагоді. Саме ці взаємини і є ключовою особливістю роману і в той же час головною відмінністю фантастики автора. Рей Бредбері відходить від своїх попередників та зосереджується на описі і розкритті взаємин Марса і Землі не тільки як різних планет, а як різних систем життєдіяльності. Саме ця відмінність виводить «Марсіанські хроніки» на особливе становище у величезному потоці світової космічної фантастики. Бредбері створює своєрідний, самобутній марсіанський світ, беручи до уваги досвід своїх попередників і також вносячи в нього свої неповторні риси. Важливо відзначити, що, незважаючи на перейнятість циклу «Марсіанських хронік» марсіанської темою, Марс у творі $\epsilon$ ще $\mathrm{i}$ метафорою, яка відображатиме проблему глибокої людської самотності [6]. Марс Бредбері оповитий атмосферою неминучої загибелі та пагубності людської раси. В останній четвертій експедиції на Марс ми бачимо остаточне знищення марсіанської раси людиною, якій не довелося докладати жодних особливих зусиль, щоб винищити цілу цивілізацію. Тут, як і в романі «Війна світів» Г. Веллса, вирішальну роль зіграв біологічний фактор: марсіани вимерли від завезеного на планету вірусу вітрянки. Цим автор хотів підкреслити думку, що людство несе 
руйнування за своєю природою. І це тягне за собою невтішні прогнози: як людство зруйнувало чужу цивілізацію, таким же чином воно зруйнує i свою. Цей прогноз проілюстрований далі: люди в поспіху залишали Землю, рятуючись від страшної війни, яку вони ж і розв'язали. Особливу увагу варто приділити передостанній главі твору під назвою «I буде ласкавий дощ». У цьому розділі зображується повністю роботизований будинок звичайної каліфорнійської сім'ї, в якому нікого немає, крім собаки (який згодом помер). I цей будинок, що згорає дотла в результаті випадкового загоряння, символізує знищення всього того, що залишилося від всієї земної цивілізації [5].

У романі «Червона планета» Р. Хайнлайна ( R. Heinlein «Red Planet») жителі Марсу - не забута цивілізація Древніх, яка залишила після себе руїни і артефакти, це цілком живе поселення зі своєю буденністю i звичними для землян проблемами, але в той же час це таємничі Древні, божественні та недоторканні мудреці. Життя на планеті підпорядковується складним кліматичним умовам: через падіння температури до $100^{\circ} \mathrm{C}$ люди вимушені кожні півроку (дорівнюють 12 земним місяцям) мігрувати з Південної в Північну Колонії. Особлива риса Колонії просторова замкнутість, усе спрямовано на захист від смертельного холоду. У повісті простежується не тільки просторова опозиція, але й культурна: світ людей з їх вадами протиставляється мудрій марсіанській цивілізації. Р. Хайнлайн 3 топографічною чіткістю змальовує Марс, називає конкретні міста, канали, описує клімат планети, природу, іiі мешканців, чим і створює ілюзію достовірності. Цікавим просторовим елементом $\epsilon$ топос древнього марсіанського міста Цинія, де герої-діти знайомляться з флегматичним марсіанином Гекко, який спочатку відштовхує їх своєю дивною зовнішністю. Р. Хайнлайн продовжує традицію С. Вейнсбаума, який робить спробу зруйнувати негативне ставлення до марсіан, закладене Г. Веллсом у «Війні світів», і діти встановлюють дружні стосунки 3 аборигеном. Взаємини землян із марсіанами для письменника - зайвий привід нагадати людству про його недосконалість та проблеми, задекларувати толерантність щодо інших рас. Цю толерантність проявляють як марсіани, так і герої-школярі: перші завдяки вродженій віковій мудрості, другі завдяки належному вихованню.

Отже, візії фантастичного світу планети Марс і марсіан у проаналізованих творах дуже різне: це й войовничі велетні, які борються за існування своєї планети, мудреці, чудернацькі створіння, друзі і кохані землян. Зображення мешканців Червоної планети дало великий поштовх для розвитку жанру наукової фантастики та стало свого роду дзеркалом для зображення землян. 


\section{Література:}

1. Burroughs E. The Princess of Mars, 1912. URL: https://en.wikisource.org/wiki/A_Princess_of_Mars (дата звернення 18.04.2021).

2. Хайнлайн Р. Красная планета: сборник. Москва: Азбука, АзбукаАттикус, 2018. 512 с.

3. Бредбері Р. Марсіанські хроніки. [Електронний ресурс]. URL: https://www.ukrlib.com.ua/world/printit.php?tid=2277 (дата звернення 18.04.2021).

4. Crossley R. Imagining Mars: A Literary History, 2011. URL: https://books.google.com.ua/books?id=v3TDEDfEPdEC\&pg=PA90\&so urce $=$ gbs_toc_r\&cad $=4 \# \mathrm{v}=$ onepage $\& \mathrm{q} \& \mathrm{f}=$ false $($ дата звернення 18.04.2021).

5. Howard V. Hendrix,, George Slusser, Eric S. Rabkin Visions of Mars: Essays on the Red Planet in Fiction and Science. McFarland, 2014. [Електронний pecypc]. URL: https://books.google.com.ua/books?id=XjI glebU6CIC\&printsec $=$ frontcover\&dq=Visions+of+Mars:+Essays+on+the+Re $\mathrm{d}+$ Planet+in+Fiction+and + Science $\& \mathrm{hl}=$ en $\&$ sa $=X \&$ ved $=2$ ahUKEwieuf32uojw AhXklIsKHZHGDZ8Q6AEwAHoECAAQAg\#v=onepage $\& \mathrm{q}=\mathrm{Visions} \% 20 \mathrm{of}$ $\% 20$ Mars $\% 3 \mathrm{~A} \% 20$ Essays\%20on\%20the\%20Red\%20Planet\%20in\%20Fiction $\% 20$ and $\% 20$ Science $\& \mathrm{f}=$ false (дата звернення 18.04.2021).

6. Ray Bradbury reveals his inspiration for Martian Chronicles [Електронний ресурc] URL: https://www.youtube.com/watch?v=VZbkq $\mathrm{ieS9o}$ (дата звернення 17.04.2021) 